\title{
Vitis rupestris B38 Confers Isolate-Specific Quantitative Resistance to Penetration by Erysiphe necator
}

\author{
Paola Barba, Lance Cadle-Davidson, Erin Galarneau, and Bruce Reisch
}

First author: Plant Breeding and Genetics Section, School of Integrative Plant Science, Cornell University, Ithaca, NY 14853; second and third authors: U.S. Department of Agriculture-Agricultural Research Service (USDA-ARS), Grape Genetics Research Unit, Geneva, NY 14456; and fourth author: Horticulture Section, School of Integrative Plant Science, Cornell University, New York State Agricultural Experiment Station, Geneva, NY 14456.

Current address of third author: USDA-ARS Crops Pathology and Genetics Research Unit, Davis, CA 95616.

Accepted for publication 13 March 2015.

\begin{abstract}
Barba, P., Cadle-Davidson, L., Galarneau, E., and Reisch, B. 2015. Vitis rupestris $\mathrm{B} 38$ confers isolate-specific quantitative resistance to penetration by Erysiphe necator. Phytopathology 105:1097-1103.

Vitis rupestris B38 is a North American grapevine resistant to the major pathogen of cultivated grapevines, Erysiphe necator. Sources of powdery mildew resistance, like $V$. rotundifolia, are widely used in grape breeding but are already threatened, even before commercialization, by isolates that can reproduce on Runl and other rotundifolia-derived breeding lines. Thus, complementary sources of resistance are needed to improve resistance durability. The segregation of foliar powdery mildew severity in an $\mathrm{F}_{1}$ family, derived from a cross of $V$. rupestris $\mathrm{B} 38 \times$ $V$. vinifera 'Chardonnay', was observed in the field over three growing seasons and in potted vines following single-isolate inoculation. A pattern

of continuous variation was observed in every instance. Mechanisms of resistance were analyzed on the resistant and susceptible parent by using microscopy to quantify the ability of the pathogen to penetrate and to form a colony on detached leaves. While 'Chardonnay' was susceptible in all tested conditions, $V$. rupestris B38 resistance was characterized by a reduction in pathogen penetration, with an effect of leaf position and significant differences among powdery mildew isolates. Segregation of the ability of the pathogen to penetrate and form a colony in $F_{1}$ individuals showed a pattern of quantitative penetration resistance with no delay or restriction on colony formation once penetration has been achieved. Moreover, V. rupestris B38 showed an enhanced penetration resistance to a powdery mildew isolate with the ability to overcome the Run1 gene, making it an interesting resistance source to prolong the durability of this gene.
\end{abstract}

North American grapevines such as Vitis rupestris have coexisted with powdery mildew, a major pathogen of cultivated grapevines ( V. vinifera), for hundreds of years. The powdery mildew fungus, Erysiphe necator, originated in the eastern United States and spread to Europe and other grape-producing regions (6), causing significant economic losses due to decreases in yield and quality, and increased fungicide applications. Despite our knowledge of the biology of the fungus and its interaction with $V$. vinifera, the durable mechanisms by which most wild North American grapevines tolerate powdery mildew have not been elucidated.

In the powdery mildew life cycle, a conidiospore germinates, forms an appressorium, and attempts to penetrate through the plant cuticle and cell wall. On a susceptible vine, it establishes a haustorium to obtain nutrients and to secrete effectors that inhibit the immune response. Plant tissues are colonized by extension and branching of hyphae, producing more appressoria and associated haustoria (26,30). In contrast, resistant plants have developed mechanisms to prevent the invasion of biotrophic pathogens. Both, preformed physical and chemical barriers (e.g., leaf surface wax and antimicrobial metabolites) and pathogen associated molecular patterns (PAMP)-triggered immunity (PTI) —also known as basal

Corresponding author: L. Cadle-Davidson;

E-mail address: lance.cadledavidson@ars.usda.gov

*The $\boldsymbol{e}$-Xtra logo stands for "electronic extra" and indicates that one supplementary table is published online.

http://dx.doi.org/10.1094/PHYTO-09-14-0260-R

This article is in the public domain and not copyrightable. It may be freely reprinted with customary crediting of the source. The American Phytopathological Society, 2015 defenses - play a relevant role in resistance against plant pathogens. In the vast majority of plant-pathogen interactions, the complex PTI response is able to prevent plant colonization. However, effector molecules released by fungal haustoria may interfere with PTI and modify the interaction toward compatibility (33). In response, plants have evolved a second layer of protection, effector-triggered immunity (ETI), characterized by a gene-for-gene interaction (21) mediated by R-genes that recognize specific effectors, triggering a cascade of reactions. As such, attacked cells undergo programmed cell death (PCD), thus limiting pathogen growth and survival by obstructing their nutrient uptake (33) and restoring resistance.

In general, the mechanisms of qualitative resistance (caused by a single gene) are better understood than quantitative resistance (due to the action of several loci). Hypotheses for quantitative disease resistance can be classified as (i) genes that regulate morphological or developmental phenotypes, (ii) alleles of genes involved in basal defense, (iii) chemical components of the plant-pathogen interaction, (iv) loci involved in defense signal transduction, (v) weak forms of R-genes, or (vi) unique forms of genes previously unidentified (41). R-genes conferring qualitative resistance against powdery mildews have been quickly overcome (10), and attempts to improve the durability by the stacking of multiple R-genes or multiple alleles of a single R-gene have only slightly extended the durability of resistance (7). In contrast, stacking of R-genes and quantitative resistance genes has been suggested to provide a more durable approach $(8,39)$.

Genes responsible for qualitative resistance to powdery mildew have been identified, mapped, and characterized; the R-genes Run1 $(2,5,18,40), \operatorname{Ren} 1(11,31)$, and Ren4 $(37,42,44)$ are dominant genes that provide qualitative resistance, usually accompanied by PCD. Utilization and stacking of some of these major genes in grapevine breeding programs has been reported $(15,34)$. 
Quantitative resistance to powdery mildew has been observed in several North American species, including V. rupestris (4). $V$. rupestris is a powdery mildew host exhibiting quantitative variation in foliar resistance among $V$. rupestris accessions $(9,14,45)$, as well as within single accessions tested in different environments (9). Microscopic analysis of the resistance mechanism of one genotype of $V$. rupestris indicated quantitative resistance, characterized by quantitatively reduced penetration success rate when compared with $V$. vinifera and low levels of PCD (18). Major quantitative trait loci (QTLs) responsible for quantitative powdery mildew resistance have been identified from North American sources. These QTLs are Ren2 from V. cinerea (12,13); Run2.1, Run2.2, and Run 5 from $V$. rotundifolia $(3,44)$; and Ren 3 from the hybrid cultivar Regent, whose pedigree includes $V$. aestivalis, $V$. berlandieri, $V$. cinerea, V. labrusca, V. lincecumii, V. riparia, and V. rupestris (20). Finally, the moderate QTL Sen1 was associated with alleles from 'Chardonnay' that increased powdery mildew severity (1).

In this work we sought to understand the genetics and mechanisms of powdery mildew resistance in $V$. rupestris B38 through a quantitative study of disease segregation in an $\mathrm{F}_{1}$ family derived from the cross of $V$. rupestris B $38 \times V$. vinifera 'Chardonnay'. Disease progression was studied using natural infections in the field and single isolate inoculations of potted vines. Furthermore, quantitative microscopy was used to compare mechanisms and powdery mildew isolate specificity of resistance in $V$. rupestris with the susceptible parent 'Chardonnay', and to study the response of progeny to single-isolate detached-leaf inoculations.

\section{MATERIALS AND METHODS}

Plant material. An $\mathrm{F}_{1}$ family of 84 vines was obtained from the cross of $V$. rupestris B38 (resistant) and $V$. vinifera 'Chardonnay' (susceptible) in 2008. Seedlings were planted first to a nursery and then established in a vineyard and cultivated as described in Barba et al. (1). Captan 80WPG, which provides no powdery mildew control under vineyard conditions, was used to control downy mildew so that otherwise healthy leaf tissue could be rated for powdery mildew resistance. A subset of the family and parental vines were vegetatively propagated in 2010 as follows: dormant cuttings were taken from the vineyard in early December, stored at $4^{\circ} \mathrm{C}$ for 5 weeks, and potted in a mixture of perlite/soil (3:1) with bottom heat at $26^{\circ} \mathrm{C}$ until sufficient rooting took place. Vines were then grown in a greenhouse under a $16 \mathrm{~h}$ photoperiod at 27 to $30^{\circ} \mathrm{C}$. Vines were pruned in order to assure uniform vegetative growth when needed.

Powdery mildew isolates. Isolates were obtained from the sources described in Table 1 and propagated weekly on 'Chardonnay' leaves as follows: leaves were surface-sterilized with $1 \%$ sodium hypochlorite for $5 \mathrm{~min}$, rinsed twice with sterile distilled water, and placed in plates containing sterile $1 \%$ agar. A leaf infected with a single isolate was tapped over a newly plated leaf. Plates were sealed with parafilm and incubated at $25 \pm 2^{\circ} \mathrm{C}$ with a $16 \mathrm{~h}$ photoperiod.

TABLE 1. Description of Erysiphe necator isolates used, including isolate name, genotype of source vine, resistance status of the source vine, and location

\begin{tabular}{|c|c|c|c|}
\hline Isolate name & Vine genotype & $\begin{array}{l}\text { Vine } \\
\text { resistance }\end{array}$ & Location \\
\hline LNYM & V. vinifera 'Merlot' & Susceptible & Lockport, $\mathrm{NY}^{\mathrm{a}}$ \\
\hline NY19 & V. vinifera 'Chardonnay' & Susceptible & Burdett, NYa \\
\hline NY90 & V. vinifera 'Chardonnay' & Susceptible & Burdett, NYa \\
\hline RoACS & $\begin{array}{l}V . \text { vinifera 'Cabernet } \\
\text { Sauvignon' }\end{array}$ & Susceptible & Hurdle Mills, $\mathrm{NC}^{\mathrm{b}}$ \\
\hline NY1-137 & Interspecific hybrid & Run1 & Geneva, $\mathrm{NY}^{\mathrm{c}}$ \\
\hline RoAwmus3 & V. rotundifolia wild type & $\begin{array}{r}\text { Presumed } \\
\text { resistant }\end{array}$ & Hurdle Mills, $\mathrm{NC}^{\mathrm{b}}$ \\
\hline
\end{tabular}

\footnotetext{
${ }^{a}$ L. Cadle-Davidson, unpublished data.

b Frenkel et al. (22).
}

c Cadle-Davidson et al. (10).
Quantification of powdery mildew penetration and colony formation on detached leaves. One hundred germinated conidia per sample (either whole leaf or leaf disc) were observed with a compound microscope and classified as having (i) a primary hypha leading to an appressorium, (ii) a single unbranched secondary hypha at least twice as long as the conidium, or (iii) multiple or branching secondary hyphae. Penetration success rate was quantified as the proportion of germinated conidia (categories i, ii, and iii) in categories ii and iii. Colony success rate was quantified as the percentage of penetrating conidia (categories ii and iii) in category iii.

Segregation of powdery mildew severity on vines. Powdery mildew infection was scored on $\mathrm{F}_{1}$ vines subject to natural disease pressure for 3 years in the vineyard. The first field evaluation was conducted once in early October 2009 using a visual index tool that classified infected vines in four categories (Table 2). This system was replaced by the IPGRI scale established by the Organization Internationale de la Vigne et du Vin utilizing a disease progression scale ranging from 1 (no visible mycelium) to 9 (strong sporulation and abundant mycelium) as described by the International Union for the Protection of New Varieties of Plants (32). This change was made to provide a better classification of infected vines, where differences between genotypes were observed (see last row in Table 2), and to standardize field evaluations among international research groups $(31,40)$. Field assessments conducted between July and September 2010 and 2011 used the IPGRI scale. In order to observe the progression of the disease during 2010, a total of four field assessments were conducted: 9, 20, and 30 August and 7 September, by which time susceptible checks were heavily infected. In 2011, field assessments were conducted on 12 July and 18 August. Pearson's correlation coefficients $(r)$ between assessments were calculated.

Single isolate inoculation was performed on replicated potted plants of $37 \mathrm{~F}_{1}$ genotypes propagated from dormant hardwood cuttings and grown in a screenhouse. Vines were infected with E. necator isolate NY90 (Table 1) using heavily sporulating colonies on 'Chardonnay' vines as a source of inoculum. Distribution of conidia was achieved by moving a box fan through each screenhouse for $2 \mathrm{~min}$. Disease severity was recorded 7, 10, and 14 days postinoculation (dpi) as the proportion of leaf surface covered by powdery mildew. Vines were organized in two replicated screenhouses, with each being a completely randomized block. Least square means were determined by analysis of variance (ANOVA) using factorial combinations of predictors: vine genotype, block, and dpi.

Foliar ontogenic resistance of $V$. rupestris $\mathrm{B38}$ and V. vinifera 'Chardonnay'. Leaf position was determined starting from the shoot tip with the first unfolded leaf designated as position one. Duplicate leaf samples from positions two to five were collected from greenhouse grown $V$. rupestris B38 and 'Chardonnay' vines. Leaves were prepared as described above. Inoculation was performed by spraying leaves with a suspension of

TABLE 2. Evaluation scale for powdery mildew on grapevine leaves in 2009

\begin{tabular}{|c|c|c|}
\hline Score & Description & IPGRI comparison \\
\hline 0 & Absent & $\begin{array}{l}\text { 1: Very low (tiny spots or no } \\
\text { symptoms, neither visible } \\
\text { sporulation nor mycelium) }\end{array}$ \\
\hline 1 & Less than five small spots & $\begin{array}{l}\text { 3: Low (limited patches }<2 \mathrm{~cm} \\
\text { in diameter, limited sporulation } \\
\text { and mycelium) }\end{array}$ \\
\hline 2 & $\begin{array}{l}\text { Five to twenty spots, } \\
\text { growing }\end{array}$ & $\begin{array}{l}\text { 5: Medium (patches usually limited } \\
\text { with a diameter of } 2 \text { to } 5 \mathrm{~cm} \text { ) }\end{array}$ \\
\hline 3 & $\begin{array}{l}\text { Widespread powdery } \\
\text { mildew, dense } \\
\text { sporulation }\end{array}$ & $\begin{array}{l}\text { 7: High (vast patches, some limited, } \\
\text { strong sporulation and abundant } \\
\text { mycelium) to 9: Very high (very vast } \\
\text { unlimited patches or totally attacked } \\
\text { leaf blades, string sporulation and } \\
\text { abundant mycelium) }\end{array}$ \\
\hline
\end{tabular}


$10^{5}$ conidia/ml of 10 -day-old LNYM in $0.001 \%$ Tween 20 . Plates containing infected leaves were air-dried in a sterile hood before being sealed with parafilm and incubated at $25 \pm 2^{\circ} \mathrm{C}$ for 2 days. Powdery mildew structures were stained using Coomassie dye (42). Quantification of powdery mildew penetration and colony formation was performed as described above.

The experiment was repeated twice. Least square means were determined by ANOVA using factorial combinations of predictors: vine genotype, experiment, and leaf position (nested within vine genotype). Mean differences were compared using Tukey's honest significant difference (HSD) test at $\alpha=0.05$.

Isolate specificity on $V_{\text {. }}$ rupestris $\mathrm{B} 38$ and $V$. vinifera 'Chardonnay'. Fully expanded leaves at the fourth position from V. rupestris B38 and 'Chardonnay' were collected from noninfected greenhouse vines and surface sterilized as described above. For each powdery mildew isolate described in Table 1, two water agar Petri dishes containing four leaf discs ( $1 \mathrm{~cm}$ diameter) from each parent were infected by touching 10-day-old sporulating colonies to the adaxial leaf disc surface. Plates were incubated at $25 \pm 2{ }^{\circ} \mathrm{C}$ for 2 days. After trypan blue staining, fungal structures and host cell death under appressoria were evaluated (18). Quantification of powdery mildew penetration and colony success rate per plate were determined as described above.

The experiment was repeated twice with a completely balanced design. Least square means were determined by ANOVA using factorial combinations of predictors: vine genotype, powdery mildew isolate and experiment. Mean values were compared using Tukey's HSD test at $\alpha=0.05$.

Segregation of powdery mildew severity on detached leaves. Leaves from a subset of $53 \mathrm{~F}_{1}$ vines and parents were used to quantify the segregation of resistance to E. necator LNYM (Table 1) under controlled in vitro conditions. Leaves at the fifth position from two growing shoots per vine were labeled, detached, and placed in distilled water for transport. Surface sterilization, spray inoculation with E. necator LNYM, incubation, Coomassie staining, and quantification of powdery mildew penetration and colony success rate were performed as described above. The experiment was repeated twice with a completely balanced design.
Least square mean values were determined by ANOVA using predictors: vine genotype and experiment.

\section{RESULTS}

Segregation of powdery mildew severity on vines. Powdery mildew severity segregated with a pattern of continuous variation whether tested under natural disease pressure in the field during three seasons (Fig. 1A to C) or with single-isolate inoculations on potted vines (Fig. 1D). Under field conditions, $V$. rupestris had little to no powdery mildew severity throughout the growing season, while 'Chardonnay' became heavily infected early in the season. Pearson's correlation coefficients $(r)$ were strongest among time points within an epidemic, such as vineyard severity at various time points within a year (Table 3 ). In addition, individual $F_{1}$ vines with low powdery mildew severity in August 2010 also had low severity in August 2011, even though their overall $r$ values ranged from 0.30 to 0.42 . At these late time points, vines $03,18,35$, $39,44,50,67,70$, and 74 had consistently lower severity than the progeny average (Supplementary Table S1). Quantitative segregation was also observed when measured as mean powdery mildew leaf coverage at 7, 10, and $14 \mathrm{dpi}$ in the potted vine assay (Fig. 1D), with genotype being a significant predictor $(P=0.0001)$. These single-isolate data from potted vines had a moderate correlation with some natural powdery mildew severity ratings in the vineyard, such as 14 dpi versus field rating on 08.20.2010 $(r=0.56)$ or on 07.12.2011 ( $r=0.39$ ) (Table 3).

Foliar ontogenic resistance of $V$. rupestris $\mathrm{B38}$ and $V$. vinifera 'Chardonnay'. Both leaf position and vine genotype were significant predictors of the penetration success rate $(P<$ 0.0001). For both $V$. rupestris B38 and 'Chardonnay', penetration success rate remained stable from the second to fourth leaf, with a reduction at the fifth leaf that was only significant in $V$. rupestris (Fig. 2). Mean differences between $V$. rupestris B38 and V. vinifera 'Chardonnay' penetration at leaf positions two, three, and four were $45.5,44.0$, and $46.8 \%$, respectively, while the mean difference at leaf position five increased to $60.3 \%$ (Fig. 2). Differences in colony success rate among leaf positions were not significant.
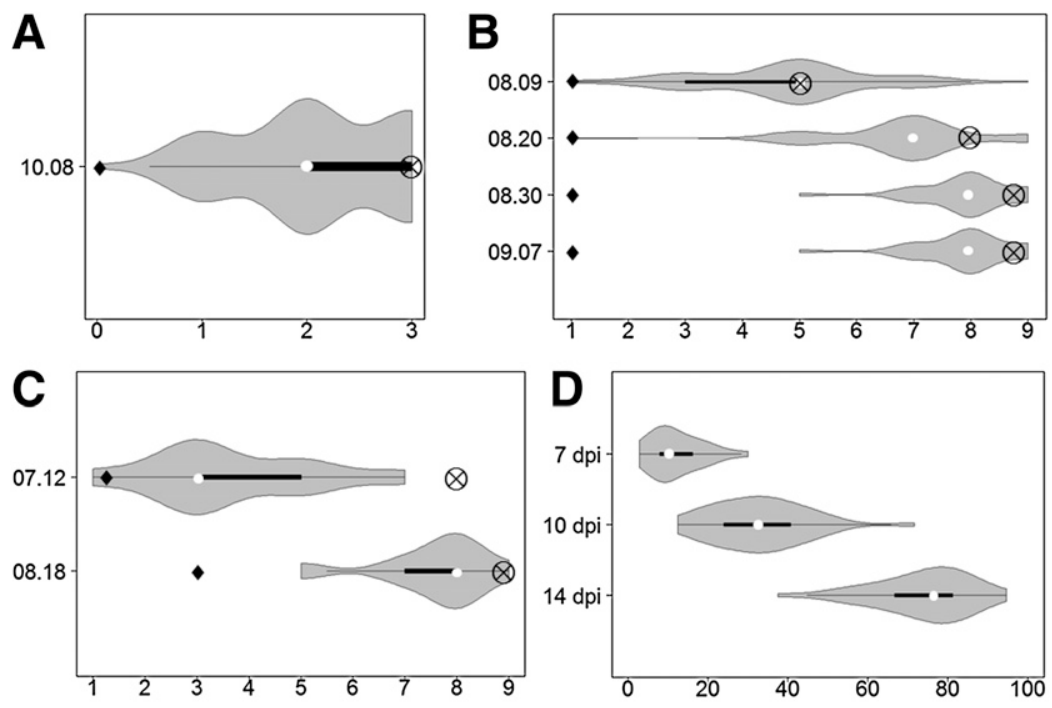

\section{Disease progression}

Fig. 1. Frequency distribution (violin plot) of powdery mildew disease progression on the progeny of Vitis rupestris B38 $(\bullet) \times V$. vinifera 'Chardonnay' $(\otimes)$ measured as follows. A, Severity on naturally infected field vines in 2009 using a 0 to 3 severity index (Table 2). B, Severity on naturally infected field vines on four dates (month.day) during the 2010 growing season, using the IPGRI scale to track disease progression (32). C, Severity on naturally infected field vines on two dates during the 2011 growing season, using the IPGRI scale. D, Least square mean leaf coverage 7, 10, and 14 days postinoculation by isolate NY90 on potted vines, measured as a percentage. The black bar within each violin indicates the interquartile range, the white dot indicates the mean value, and the overlaid gray area indicates the probability density. Symbols $\bullet$ and $\otimes$ indicate the value for parental genotypes V. rupestris B38 and V. vinifera 'Chardonnay', respectively. 
Isolate specificity on $V$. rupestris $\mathrm{B38}$ and $V$. vinifera 'Chardonnay'. Vine genotype was the most significant predictor of penetration and colony success rates at the fourth leaf position $(P<0.0001)$, while powdery mildew isolate was a significant factor for penetration success rate $(P<0.0001)$, but not for colony success rate $(P=0.1246)$. On $V$. vinifera 'Chardonnay', penetration success rates did not differ significantly among the six isolates. Penetration success rates ranged from 77 to $93 \%$ on 'Chardonnay', and 95 to $99 \%$ of penetrating conidia formed a colony (Fig. 3). In contrast, the penetration success rate on $V$. rupestris $\mathrm{B} 38$ was significantly lower $(P<0.001)$ and varied among isolates $(P<0.001)$. Erysiphe necator isolates collected from $V$. vinifera ranged from 49 to $26 \%$ of the germinated conidia, while isolate RoAwmus3 (from $V$. rotundifolia) had a $16 \%$ penetration success rate. The least virulent $E$. necator isolate on $V$. rupestris B38 was NY1-137, collected from a hybrid vine with the Runl gene from $V$. rotundifolia (10), with a $7 \%$ penetration success rate (Fig. 3). Host cell death under appressoria was infrequent at $48 \mathrm{~h}$ postinoculation in 'Chardonnay' and V. rupestris B38 leaves (Fig. 4).

Segregation of powdery mildew severity on detached leaves. On the fifth fully expanded leaf, penetration success rate of E. necator LNYM segregated with a pattern of continuous distribution (Fig. 5). LNYM penetrated 'Chardonnay' with a 10fold higher success rate than $V$. rupestris B38. Once penetration occurred, the colony success rate for the susceptible parent and $F_{1}$ progeny was close to $100 \%$, and never lower than the resistant parent (80\%) (Fig. 5). In both penetration and colony ratings, genotype was a significant predictor $(P<0.0001)$.

\section{DISCUSSION}

We characterized $V$. rupestris B38 resistance to powdery mildew and found continuous variation in disease severity, supporting previous findings of polygenic inheritance of powdery mildew resistance in $V$. rupestris (4). Factors involved in quantitative disease resistance were analyzed, showing evidence for enhanced penetration resistance and increased ontogenic resistance in $V$. rupestris B38 compared with 'Chardonnay', along with a differential response to pathogen genotypes, most notably including enhanced resistance to an isolate able to overcome Run1 gene. Together, these findings allowed us to hypothesize that $V$. rupestris resistance is due to the action of several mechanisms, making it an interesting source of quantitative resistance to powdery mildew that may enhance the durability of Runl resistance.

Resistance in $V$. rupestris $\mathrm{B} 38 \times V$. vinifera 'Chardonnay' progeny segregated in a quantitative manner. While $V$. rupestris B38 had little to no powdery mildew infection throughout the season, the mean infection of the progeny tended toward susceptibility by the end of the season, but lagged behind the susceptibility of 'Chardonnay' (Fig. 1). Quantitative variation in the resistance response can be due to genetic and environmental effects. In this work, powdery mildew resistance was evaluated over 3 years, and a quantitative segregation pattern was observed in every instance, with a moderate correlation between field seasons (Table 3). Compared with other crops where replicated field trials are often used, cost and labor requirements restrain the number of vines placed in a vineyard, limiting the use of replicate vines in favor of planting more genotypes. In order to reduce environmental variance, a subset of the segregating family was screened with a single isolate in both replicated potted vine assays and detached leaf assays. Those results corroborated the continuous variation pattern found in field assessments, and ANOVA showed significance of vine genotype in the prediction of the observed phenotype for both the potted vine assay $(P<0.0001)$ and detached leaf assay $(P<0.0001)$.

Furthermore, in our experiments, $V$. rupestris resistance did not resemble the qualitative resistance from other Vitis sources. Our results are strikingly different from the observed phenotypes on Ren 4 or Runl vines, where no powdery mildew was observed on resistant genotypes, with test crosses segregating in a 1:1 ratio in either field or greenhouse evaluations $(2,40,42)$. Moreover,

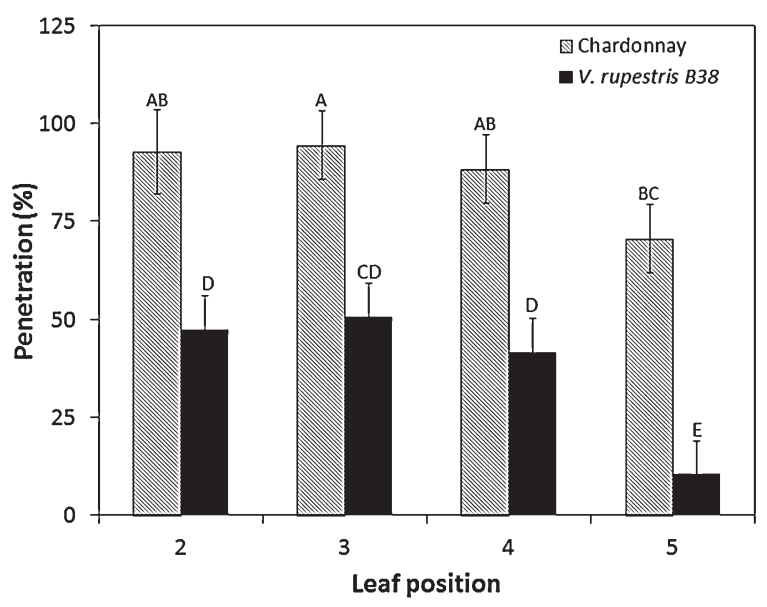

Fig. 2. Effect of leaf position on Erysiphe necator isolate LNYM penetration success rate on parent genotypes Vitis vinifera 'Chardonnay' and V. rupestris B38. The ability of powdery mildew to penetrate was calculated as the percentage of germinated conidiospores forming at least one secondary hypha by 2 days postinoculation. Error bars indicate $95 \%$ confidence limits, and letters above bars indicate statistically significant differences in penetration success rate (Tukey's honest significant difference test at $P<0.05$ ).

TABLE 3. Correlations between powdery mildew ratings ${ }^{\mathrm{a}}$

\begin{tabular}{|c|c|c|c|c|c|c|c|c|c|c|c|c|c|c|}
\hline $\begin{array}{l}\text { Type of } \\
\text { inoculum }\end{array}$ & $\begin{array}{c}\text { Assay } \\
\text { condition }\end{array}$ & Observation & 10.08 .09 & 08.09.10 & 08.20 .10 & 08.30 .10 & 09.07 .10 & 07.12 .11 & 08.18 .11 & 7 dpi & 10 dpi & 14 dpi & Penetration & Colony \\
\hline \multirow[t]{6}{*}{ Natural } & Field & 10.08 .09 & 1.00 & & & & & & & & & & & \\
\hline & & 08.09 .10 & 0.38 & 1.00 & & & & & & & & & & \\
\hline & & 08.30 .10 & 0.26 & 0.45 & 0.66 & 1.00 & & & & & & & & \\
\hline & & 09.07 .10 & 0.40 & 0.55 & 0.60 & 0.56 & 1.00 & & & & & & & \\
\hline & & 07.12 .11 & 0.07 & 0.37 & 0.37 & 0.18 & 0.22 & 1.00 & & & & & & \\
\hline & & 08.18 .11 & 0.19 & 0.42 & 0.35 & 0.30 & 0.29 & 0.44 & 1.00 & & & & & \\
\hline \multirow{4}{*}{ isolate } & & $14 \mathrm{dpi}$ & 0.16 & 0.31 & 0.56 & 0.32 & 0.43 & 0.39 & 0.36 & 0.49 & 0.77 & 1.00 & & \\
\hline & Petri dish & Penetration & 0.03 & 0.10 & 0.19 & 0.17 & -0.14 & 0.22 & 0.03 & -0.09 & 0.27 & 0.10 & 1.00 & \\
\hline & & Colony & 0.00 & 0.10 & 0.07 & 0.02 & -0.21 & 0.10 & 0.05 & 0.16 & 0.39 & 0.22 & 0.76 & 1.00 \\
\hline & & $\begin{array}{l}\text { Number of } \\
\text { genotypes }\end{array}$ & 82 & 84 & 84 & 84 & 84 & 72 & 72 & 37 & 37 & 37 & 53 & 53 \\
\hline
\end{tabular}

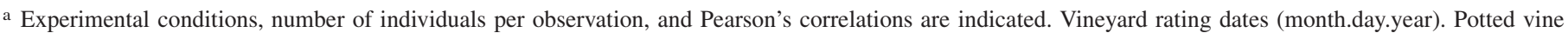
severity was rated 7, 10, and 14 days postinoculation (dpi) with Erysiphe necator isolate NY90. Detached leaves in Petri dishes were rated for penetration and colony success rate $48 \mathrm{~h}$ postinoculation with E. necator isolate LNYM.
} 
microscopic characterization of E. necator interactions with vine genotypes bearing Runl or Renl genes have shown the presence of PCD under appressoria associated with ETI responses triggered by $\mathrm{R}$-genes $(17,31)$. In contrast, we did not observe frequent host cell death with any isolates tested on $V$. rupestris B38. All these differences lead us to reject the hypothesis that the $V$. rupestris B38 mechanism of resistance to powdery mildew is controlled by a single R-gene, and raises the question of which mechanisms contribute to its quantitative resistance.

Penetration resistance. One mechanism of resistance of $V$. rupestris $\mathrm{B} 38$ was a reduction in penetration success rate of E. necator at 2 dpi on all leaf ages observed (Fig. 2). An increased number of conidia were arrested at the appressorium formation stage (Figs. 3 and 4B), compared with 'Chardonnay' where the vast majority of germinated conidia were able to penetrate and create a colony (Figs. 3 and 4A). In their progeny, the penetration success rate segregated in a quantitative pattern skewed toward susceptibility, which suggests that more than one allele and/or locus from V. rupestris B38 may be required for full resistance (Fig. 5), possibly combined with the action of susceptibility alleles from the $V$. vinifera parent (1). Here, we describe the $V$. rupestris $\mathrm{B} 38$ response as quantitative penetration resistance with no significant $\mathrm{PCD}$ observed. This agrees with previous findings following inoculation with another powdery mildew isolate onto a different $V$. rupestris genotype, which also had quantitative resistance, characterized by having $44 \%$ of germinated spores failing to penetrate, and low levels of PCD (18). In V. rupestris B38 we found significant differences in the ability to penetrate the epidermis and establish secondary hypha, accompanied by a high percentage of successful colonies once penetration had been achieved (Fig. 3). Also, the colony success rate was consistently high across segregating progeny (90 to $100 \%$, Fig. 5), indicating that, unlike Renl (31), V. rupestris B38 mechanisms of resistance do not slow colony formation. That is, once a haustorium is established and a secondary hypha is formed, there is minimal resistance to the formation of a colony.

Penetration resistance can be due to the effect of preformed barriers or of PTI. In Vitis species, the involvement of these mechanisms in the interaction with powdery mildew has been reported. At the transcriptome level, susceptible $V$. vinifera vines responded with defense oriented reprogramming that failed to prevent powdery mildew infection, while a resistant cultivar, the V. aestivalis-derived interspecific hybrid cultivar Norton, showed enhanced transcription of a few genes related to basal defense, which corresponded with a quantitatively increased penetration-resistance phenotype (24).
Other studies have focused on critical pathways for the nonhost response, such as actin cytoskeleton formation and vesicle trafficking. While actin cytoskeleton formation was shown to be partially required for nonhost and host resistance, vesicle trafficking was

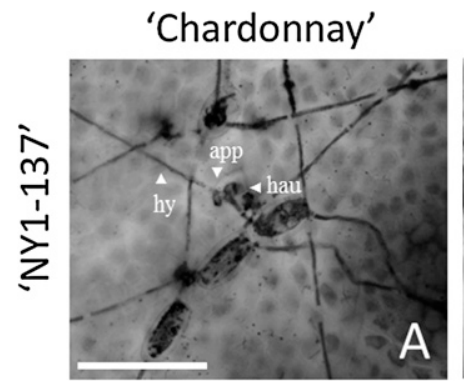

\section{V. rupestris $\mathrm{B} 38$}

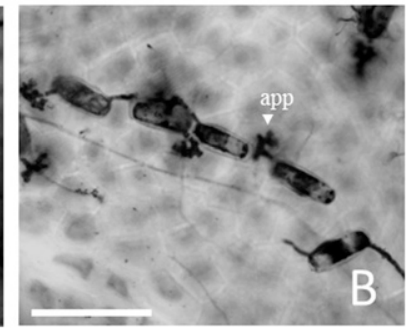

Fig. 4. Interaction of Erysiphe necator isolate NY1-137 on Vitis vinifera 'Chardonnay' and V. rupestris B38. A, Compatible interaction of isolate NY1137 on $V$. vinifera 'Chardonnay' showing appressorium (app $\mathbf{\nabla}$ ), haustorium ( $\downarrow$ hau), and multiple hyphae ( $\Delta$ hy). B, Incompatible interaction (penetration resistance) of isolate NY1-137 on V. rupestris B38, characterized by a high frequency of germinated conidia arrested in appressorium formation (app $\boldsymbol{\nabla})$. Scale bars $=50 \mu \mathrm{m}$.

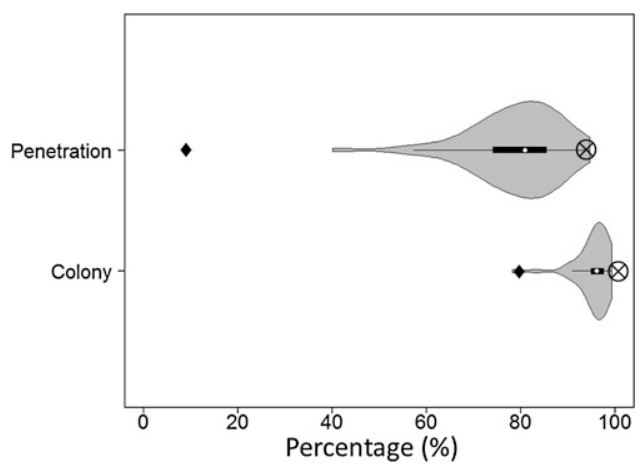

Fig. 5. Frequency distribution (violin plot) of penetration success rate and colony success rate of single isolate LNYM on the progeny of Vitis rupestris B38 $(\diamond) \times V$. vinifera 'Chardonnay' $(\otimes)$. Penetration was measured as the percentage of germinated conidiospores forming at least one secondary hypha, and colony success rate as the percentage of penetrating conidiospores generating multiple hyphae. A black bar within each violin indicates the interquartile range, white dot indicates the mean value of the sample, and the overlaid gray area indicates the probability density of the sample.

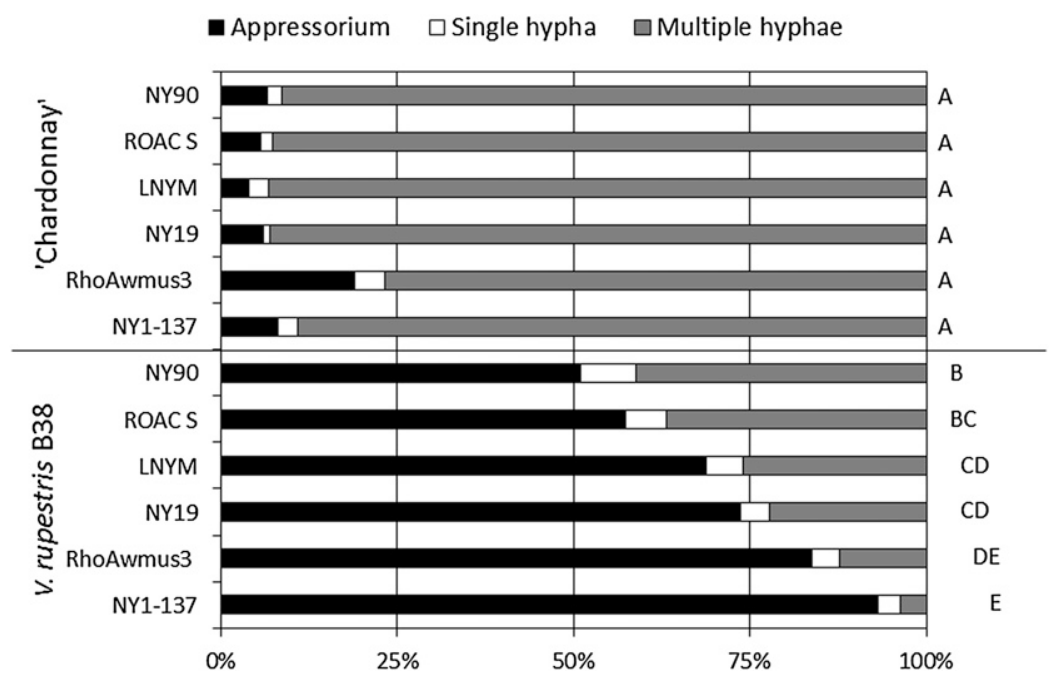

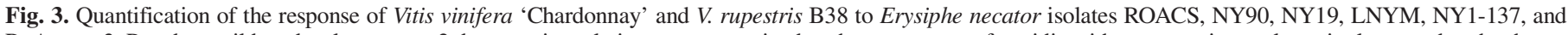

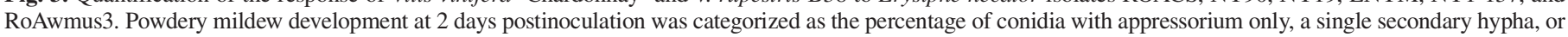

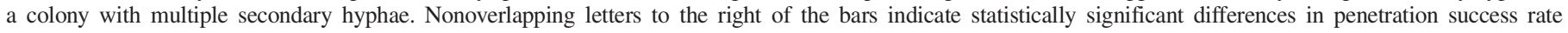
measured as the percentage of germinated conidiospores forming at least one secondary hypha (Tukey honest significant difference test at $P<0.05$ ). 
shown to be required by $E$. necator to establish a compatible interaction with susceptible grapevines (18). We favor a hypothesis that the specific mechanism involved in $V$. rupestris B38 enhanced penetration resistance could relate to one or more quantitative factors underlying basal defenses, with the effectors of some isolates (e.g., NY1-137) unable to overcome the basal defenses.

Isolate specificity. Variation in powdery mildew response to $V$. rupestris has been reported under different conditions. In CadleDavidson et al. $(9,10)$ a detached leaf assay with $V$. rupestris B38, with a single powdery mildew isolate, showed no infection $21 \mathrm{dpi}$, but natural infection was observed at two field locations. In our experience, $V$. rupestris B38 showed no infection in the nursery (year 1) or in its first year of establishment in a vineyard (year 2), but low levels of infection in year 3 (Fig. 1). Seasonal variation can be due to maturity differences of the vines, variable inoculum pressure, environment, and canopy density. In addition, some of the observed variation may be explained by genotypic differences of pathogen populations over time. In our experiments, seedlings were maintained in a no-spray nursery with extreme levels of powdery mildew on some vines, and then planted to a permanent vineyard in which 'Chardonnay' vines with high levels of powdery mildew were interspersed (Fig. 1A to C). This local source of inoculum and capacity for recurrent adaptation and selection on vines carrying resistance alleles could explain the earlier appearance of symptoms observed each year (Fig. 1), the switch in relative resistance of some progeny over seasons and the lower correlation among years $(r<0.42$, Table 3$)$, compared with correlations within years $(r>0.44$, Table 3$)$. This, combined with the evidence for races within powdery mildew populations (43) and the high genetic diversity found among isolates from Geneva, NY (23), created an argument for studying the interaction of $V$. rupestris B38 with a panel of $E$. necator isolates of powdery mildew and a singleisolate assay of the progeny in order to reduce the influence powdery mildew genetic variation on resistance ratings (Fig. 1D).

Although we did not observe a classic qualitative gene-for-gene interaction of $V$. rupestris B38 with E. necator, at a microscopic level it was possible to detect significant differences in penetration success rate among powdery mildew isolates, without frequent cell death under the appressorium in all cases. Isolates coming from $V$. vinifera sources showed significantly higher penetration success rates on $V$. rupestris B38 than those isolated from resistant vines, including $V$. rotundifolia or interspecific hybrid vines with the Run 1 gene introgressed from $V$. rotundifolia (Fig. 3, Table 1). Consistent with previous findings $(22,23,25)$, isolates showed no significant differences in growth on $V$. vinifera. Thus, the continuous variation observed in the virulence of isolates on $V$. rupestris B38 reflects a differential response of each isolate to resistance loci rather than a fitness cost. This continuous variation could be due to variation among isolates in effectors of small additive consequence involved in the suppression of basal defenses.

These results contrast with studies in transgenic vines carrying the Runl locus, where powdery mildew isolates from $V$. rotundifolia were able to overcome the Runl gene, and powdery mildew isolates from $V$. vinifera sources were stopped by a hypersensitive response characterized by PCD (17). Our findings suggest that $V$. rupestris $\mathrm{B} 38$ powdery mildew resistance may complement the effect of Run 1, helping prolong the durability of this resistance gene.

In V. vinifera 'Chardonnay', all isolates showed similar high levels of penetration (Fig. 3). The ease of infection on 'Chardonnay' leaves regardless of the isolate may indicate the presence of susceptibility factors that allow E. necator to infect 'Chardonnay' more efficiently than $V$. rupestris B38. This observation correlates with recent findings of a susceptible QTL in 'Chardonnay' (1).

Developmental stage. In other crops like barley or wheat, the genetics of adult-plant resistance are characterized by slowing powdery mildew infection and extending the latent period, thereby providing incomplete but durable resistance $(35,36,46)$. In grapevines, a direct relationship between developmental stages and powdery mildew resistance has been reported; from broad observations on field assessments $(16,28,47)$ to detailed characterization of penetration resistance on berries $(9,19,27,29)$, and macroscopic resistance on grapevine leaves $(14,38)$.

Here we showed that the ability of E. necator to penetrate and establish a colony was also influenced by leaf maturity. We observe both an overall differential penetration success rate between V. rupestris B38 and 'Chardonnay' and significant differences among leaf positions within each vine genotype (Fig. 2). Maximum severity of powdery mildew penetration was observed at the third leaf for both $V$. rupestris B38 and 'Chardonnay' (50.5 and 94.5\%, respectively), which has been correlated with the carbohydrate sink-to-source transition (38). We observed that $V$. rupestris B38 developed resistance faster than 'Chardonnay', showing a further reduction of penetration success rate from $50.5 \%$ in the third leaf to $10.3 \%$ in the fifth leaf, compared with a reduction from $94.5 \%$ in the third leaf to $70.7 \%$ in the fifth leaf of 'Chardonnay'. Thus, in addition to enhanced penetration resistance, $V$. rupestris B38 vines deploy a less susceptible canopy compared with 'Chardonnay'.

Isolate-specific segregation. Here we presented a quantitative method to assess the response of the progeny against a single isolate. Using this approach, we observed a quantitative segregation pattern for penetration success rate at $2 \mathrm{dpi}$ in progeny from $V$. rupestris B38 and 'Chardonnay' and uniformly compatible responses after penetration of isolate LNYM. Given the control of environmental and pathogen variability at a precise leaf age, this approach is a simplification of the conditions of a vine in the field. While detached leaf assays enable controlled screening for the dissection of resistance mechanisms and potentially the underlying quantitative trait loci, detached leaf assays likely do not capture the complete basis of field resistance. Thus, we recommend the continued use of field trials as a complementary tool for resistance evaluation and selection.

In this work, we showed that $V$. rupestris B38 resistance to powdery mildew segregates in a quantitative manner under field as well as controlled conditions. The components of resistance include: isolate-specific penetration resistance that is enhanced on older leaves, with neither prominent PCD nor colony resistance. Moreover, we identified $V$. rupestris B38 as highly resistant to penetration for powdery mildew isolates able to overcome $V$. rotundifolia-derived resistance. Based on this observation, we suggest the use of $V$. rupestris B38 as a genetic source of quantitative resistance to powdery mildew, which when combined with other sources of resistance such as Runl, may provide improved and extended resistance against powdery mildew.

\section{ACKNOWLEDGMENTS}

We thank A. Feechan, N. Consolie, J. Burr, J. Lillis, and D. Gadoury for their advice and help with powdery mildew propagation and maintenance; P. Wallace and S. Luce for their help in vineyard maintenance and vegetative propagation; and W. Wilcox, B. Seem, and M. Mazourek for allowing use of their labs. This research was supported by Becas Chile, the USDA Viticulture Consortium-East, the New York Wine \& Grape Foundation, and the Lake Erie Regional Grape Processors Fund. Mention of trade names or commercial products is solely for the purpose of providing specific information and does not imply recommendation or endorsement by the U.S. Department of Agriculture.

\section{LITERATURE CITED}

1. Barba, P., Cadle-Davidson, L., Harriman, J., Glaubitz, J., Brooks, S., Hyma, K., and Reisch, B. 2014. Grapevine powdery mildew resistance and susceptibility loci identified on a high-resolution SNP map. Theor. Appl. Genet. 127:73-84.

2. Barker, C. L., Donald, T., Pauquet, J., Ratnaparkhe, M. B., Bouquet, A., Adam-Blondon, A. F., Thomas, M. R., and Dry, I. 2005. Genetic and physical mapping of the grapevine powdery mildew resistance gene, 
Runl, using a bacterial artificial chromosome library. Theor. Appl. Genet. 111:370-377.

3. Blanc, S., Wiedemann-Merdinoglu, S., Dumas, V., Mestre, P., and Merdinoglu, D. 2012. A reference genetic map of Muscadinia rotundifolia and identification of Ren5, a new major locus for resistance to grapevine powdery mildew. Theor. Appl. Genet. 125:1663-1675.

4. Boubals, D. 1961. Étude des causes de la résistance des Vitacées à l'Oïdium de la vigne (Uncinula necator (Schw.) Burr.) et de leur mode de transmission héréditaire. Ann. Amélior. Plant 11:401-500.

5. Bouquet, A. 1986. Introduction dans l'espèce Vitis vinifera L. d'un caractère de résistance à l'oidium (Uncinula necator Schw. Burr.) issu de l'espèce Muscadinia rotundifolia (Michx.) Small. Vignevini 12:141-146.

6. Brewer, M., and Milgroom, M. 2010. Phylogeography and population structure of the grape powdery mildew fungus, Erysiphe necator, from diverse Vitis species. BMC Evol. Biol. 10:268.

7. Brown, J. K. M. 1995. Pathogens' responses to the management of disease resistance genes. Adv. Plant Pathol. 11:75-102.

8. Brun, H., Chèvre, A.-M., Fitt, B. D. L., Powers, S., Besnard, A.-L., Ermel, M., Huteau, V., Marquer, B., Eber, F., Renard, M., and Andrivon, D. 2010. Quantitative resistance increases the durability of qualitative resistance to Leptosphaeria maculans in Brassica napus. New Phytol. 185:285-299.

9. Cadle-Davidson, L., Chicoine, D. R., and Consolie, N. H. 2011. Variation within and among Vitis spp. for foliar resistance to the powdery mildew pathogen Erysiphe necator. Plant Dis. 95:202-211.

10. Cadle-Davidson, L., Mahanil, S., Gadoury, D. M., Kozma, P., and Reisch, B. I. 2011. Natural infection of Run1-positive vines by naive genotypes of Erysiphe necator. Vitis 50:173-175.

11. Coleman, C., Copetti, D., Cipriani, G., Hoffman, S., Kozman, P., Kovacs, L., Morgante, M., Testolin, R., and Di Gaspero, G. 2009. The powdery mildew resistance gene REN1 co-segregates with an NBS-LRR gene cluster in two Central Asian grapevines. BMC Genet. 10:89.

12. Dalbó, M. 1998. Genetic mapping, QTL analysis and marker-assisted selection for disease resistance loci in grapes. Thesis. Cornell University, NY.

13. Dalbó, M. A., Ye, G. N., Weeden, N. F., Wilcox, W. F., and Reisch, B. I. 2001. Marker-assisted selection for powdery mildew resistance in grapes. J. Am. Soc. Hortic. Sci. 126:83-89.

14. Doster, M. A., and Schnathorst, W. C. 1985. Comparative susceptibility of various grapevine cultivars to the powdery mildew fungus Uncinula necator. Am. J. Enol. Vitic. 36:101-104.

15. Eibach, R., Zyprian, E., Welter, L. J., and Topfer, R. 2007. The use of molecular markers for pyramiding resistance genes in grapevine breeding. Vitis 46:120-125.

16. Evans, K., Whisson, D., and Scott, E. 1996. An experimental system for characterizing isolates of Uncinula necator. Mycol. Res. 100:675-680.

17. Feechan, A., Anderson, C., Torregrosa, L., Jermakow, A., Mestre, P., Wiedemann-Merdinoglu, S., Merdinoglu, D., Walker, A. R., Cadle-Davidson, L., Reisch, B., Aubourg, S., Bentahar, N., Shrestha, B., Bouquet, A., Adam-Blondon, A.-F., Thomas, M. R., and Dry, I. B. 2013. Genetic dissection of a TIR-NB-LRR locus from the wild North American grapevine species Muscadinia rotundifolia identifies paralogous genes conferring resistance to major fungal and oomycete pathogens in cultivated grapevine. Plant J. 76:661-674.

18. Feechan, A., Kabbara, S., and Dry, I. B. 2011. Mechanisms of powdery mildew resistance in the Vitaceae family. Mol. Plant Pathol. 12:263-274.

19. Ficke, A., Gadoury, D. M., Seem, R. C., Godfrey, D., and Dry, I. B. 2004. Host barriers and responses to Uncinula necator in developing grape berries. Phytopathology 94:438-445.

20. Fischer, B. M., Salakhutdinov, I., Akkurt, M., Eibach, R., Edwards, K. J., Topfer, R., and Zyprian, E. M. 2004. Quantitative trait locus analysis of fungal disease resistance factors on a molecular map of grapevine. Theor. Appl. Genet. 108:501-515.

21. Flor, H. H. 1942. Inheritance of pathogenicity in a cross between physiologic races 22 and 24 of Melampsora lini. Phytopathology 32:653-669.

22. Frenkel, O., Brewer, M., and Milgroom, M. 2010. Variation in pathogenicity and aggressiveness of Erysiphe necator from different Vitis species and geographic origins in the eastern United States. Phytopathology 100:1185-1193.

23. Frenkel, O., Portillo, I., Brewer, M. T., Péros, J. P., Cadle-Davidson, L., and Milgroom, M. G. 2012. Development of microsatellite markers from the transcriptome of Erysiphe necator for analysing population structure in North America and Europe. Plant Pathol. 61:106-119.

24. Fung, R., Gonzalo, M., Fekete, C., Kovacs, L., He, Y., Marsh, E., McIntyre, L., Schachtman, D., and Qiu, W. 2008. Powdery mildew induces defense-oriented reprogramming of the transcriptome in a susceptible but not in a resistant grapevine. Plant Physiol. 146:236-249.

25. Gadoury, D., and Pearson, R. 1991. Heterothallism and pathogenic specialization in Uncinula necator. Phytopathology 81:1287-1293.

26. Gadoury, D. M., Cadle-Davidson, L., Wilcox, W. F., Dry, I. B., Seem, R. C., and Milgroom, M. G. 2012. Grapevine powdery mildew (Erysiphe necator): A fascinating system for the study of the biology, ecology and epidemiology of an obligate biotroph. Mol. Plant Pathol. 13:1-16.

27. Gadoury, D. M., Seem, R. C., Ficke, A., and Wilcox, W. F. 2003. Ontogenic resistance to powdery mildew in grape berries. Phytopathology 93:547-555.

28. Gadoury, D. M., Seem, R. C., Pearson, R. C., Wilcox, W. F., and Dunst, R. M. 2001. Effects of powdery mildew on vine growth, yield, and quality of Concord grapes. Plant Dis. 85:137-140.

29. Gee, C. T., Gadoury, D. M., and Cadle-Davidson, L. 2008. Ontogenic resistance to Uncinula necator varies by genotype and tissue type in a diverse collection of Vitis spp. Plant Dis. 92:1067-1073.

30. Glawe, D. A. 2008. The powdery mildews: A review of the world's most familiar (yet poorly known) plant pathogens. Annu. Rev. Phytopathol. 46: 27-51.

31. Hoffmann, S., Di Gaspero, G., Kovács, L., Howard, S., Kiss, E., Galbács, Z., Testolin, R., and Kozma, P. 2008. Resistance to Erysiphe necator in the grapevine 'Kishmish vatkana' is controlled by a single locus through restriction of hyphal growth. Theor. Appl. Genet. 116:427-438.

32. IPGRI, UPOV, and OIV. 1997. Descriptors for grapevine (Vitis spp.). Edited by G. International Union for the Protection of New Varieties of Plants, Switzerland/Office International de la Vigne et du Vin, Paris, France. International Plants Genetics Resources Institute, Rome, Italy.

33. Jones, J. D. G., and Dangl, J. L. 2006. The plant immune system. Nature 444:323-329.

34. Katula-Debreceni, D., Lencsés, A. K., Szőke, A., Veres, A., Hoffmann, S., Kozma, P., Kovács, L. G., Heszky, L., and Kiss, E. 2010. Marker-assisted selection for two dominant powdery mildew resistance genes introgressed into a hybrid grape population. Sci. Hortic. (Amsterdam) 126:448-453.

35. Keller, M., Keller, B., Schachermayr, G., Winzeler, M., Schmid, J. E., Stamp, P., and Messmer, M. M. 1999. Quantitative trait loci for resistance against powdery mildew in a segregating wheat $\times$ spelt population. Theor. Appl. Genet. 98:903-912.

36. Liu, S., Griffey, C. A., and Maroof, M. A. S. 2001. Identification of molecular markers associated with adult plant resistance to powdery mildew in common wheat cultivar massey. Crop Sci. 41:1268-1275.

37. Mahanil, S., Ramming, D. W., Cadle-Davidson, M., Owens, C. L., Garris, A., Myles, S., and Cadle-Davidson, L. 2012. Development of marker sets useful in the early selection of Ren4 powdery mildew resistance and seedlessness for table and raisin grape breeding. Theor. Appl. Genet. 124: 23-33.

38. Merry, A. M., Evans, K. J., Corkrey, R., and Wilson, S. J. 2013. Coincidence of maximum severity of powdery mildew on grape leaves and the carbohydrate sink-to-source transition. Plant Pathol. 62:842-850.

39. Palloix, A., Ayme, V., and Moury, B. 2009. Durability of plant major resistance genes to pathogens depends on the genetic background, experimental evidence and consequences for breeding strategies. New Phytol. 183:190-199.

40. Pauquet, J., Bouquet, A., This, P., and Adam-Blondon, A. F. 2001. Establishment of a local map of AFLP markers around the powdery mildew resistance gene Runl in grapevine and assessment of their usefulness for marker assisted selection. Theor. Appl. Genet. 103:1201-1210.

41. Poland, J. A., Balint-Kurti, P. J., Wisser, R. J., Pratt, R. C., and Nelson, R. J. 2009. Shades of gray: The world of quantitative disease resistance. Trends Plant Sci. 14:21-29.

42. Ramming, D. W., Gabler, F., Smilanick, J., Cadle-Davidson, M., Barba, P., Mahanil, S., and Cadle-Davidson, L. 2011. A single dominant locus, Ren4, confers rapid non-race-specific resistance to grapevine powdery mildew. Phytopathology 101:502-508.

43. Ramming, D. W., Gabler, F., Smilanick, J. L., Margosan, D. A., Cadle-Davidson, M., Barba, P., Mahanil, S., Frenkel, O., Milgroom, M. G., and Cadle-Davidson, L. 2011. Identification of race-specific resistance in North American Vitis spp. limiting Erysiphe necator hyphal growth. Phytopathology 102:83-93.

44. Riaz, S., Tenscher, A., Ramming, D., and Walker, M. 2011. Using a limited mapping strategy to identify major QTLs for resistance to grapevine powdery mildew (Erysiphe necator) and their use in marker-assisted breeding. Theor. Appl. Genet. 122:1059-1073.

45. Staudt, G. 1997. Evaluation of resistance to grapevine powdery mildew (Uncinula necator Schw. Burr., anamorph Oidium tuckeri Berk.) in accessions of Vitis species. Vitis 36:151-154.

46. Tucker, D., Griffey, C., Liu, S., Brown-Guedira, G., Marshall, D., and Maroof, M. 2007. Confirmation of three quantitative trait loci conferring adult plant resistance to powdery mildew in two winter wheat populations. Euphytica 155:1-13.

47. Valdés-Gómez, H., Gary, C., Cartolaro, P., Lolas-Caneo, M., and Calonnec, A. 2011. Powdery mildew development is positively influenced by grapevine vegetative growth induced by different soil management strategies. Crop Prot. 30:1168-1177. 